Article

\title{
Synthesis and Biological Evaluation of RGD-Cryptophycin Conjugates for Targeted Drug Delivery
}

\author{
Adina Borbély ${ }^{1}{ }^{(0}$, Eduard Figueras ${ }^{1}{ }^{(0}$, Ana Martins ${ }^{1,2}{ }^{\circledR}$, Simone Esposito ${ }^{3}{ }^{(}$, \\ Giulio Auciello ${ }^{3}{ }^{-0}$, Edith Monteagudo ${ }^{3}$, Annalise Di Marco ${ }^{3}$, Vincenzo Summa ${ }^{3}$, \\ Paola Cordella ${ }^{4}$, Raffaella Perego ${ }^{4}$, Isabell Kemker ${ }^{1}$ (D), Marcel Frese ${ }^{1}$ (D), Paola Gallinari ${ }^{2}$, \\ Christian Steinkühler ${ }^{2,4}$ (D) and Norbert Sewald 1,*(D) \\ 1 Organic and Bioorganic Chemistry, Department of Chemistry, Bielefeld University, Universitätsstraße 25, \\ DE-33615 Bielefeld, Germany; adina.borbely@uni-bielefeld.de (A.B.); eduard.figueras@uni-bielefeld.de (E.F.); \\ ana_martins@exiris.it (A.M.); isabell.kemker@uni-bielefeld.de (I.K.); marcel.frese@uni-bielefeld.de (M.F.) \\ 2 Exiris s.r.l., Via di Castel Romano 100, IT-00128 Rome, Italy; paola_gallinari@exiris.it (P.G.); \\ christian_steinkuhler@exiris.it (C.S.) \\ 3 IRBM S.p.A, Via Pontina km. 30,600, IT-00071 Pomezia (Rome), Italy; s.esposito@irbm.com (S.E.); \\ g.auciello@irbm.com (G.A.); e.monteagudo@irbm.com (E.M.); a.dimarco@irbm.com (A.D.M.); \\ v.summa@irbm.com (V.S.) \\ 4 Italfarmaco S.p.A., Via dei Lavoratori, 54, IT-20092 Cinisello Balsamo (Milano), Italy; \\ p.cordella@italfarmaco.com (P.C.); r.perego@italfarmaco.com (R.P.) \\ * Correspondence: norbert.sewald@uni-bielefeld.de; Tel.: +49-521-106-2051
}

Received: 26 February 2019; Accepted: 25 March 2019; Published: 1 April 2019

check for updates

\begin{abstract}
Cryptophycins are potent tubulin polymerization inhibitors with picomolar antiproliferative potency in vitro and activity against multidrug-resistant (MDR) cancer cells. Because of neurotoxic side effects and limited efficacy in vivo, cryptophycin-52 failed as a clinical candidate in cancer treatment. However, this class of compounds has emerged as attractive payloads for tumor-targeting applications. In this study, cryptophycin was conjugated to the cyclopeptide $c$ (RGDfK), targeting integrin $\alpha_{\mathrm{v}} \beta_{3}$, across the protease-cleavable Val-Cit linker and two different self-immolative spacers. Plasma metabolic stability studies in vitro showed that our selected payload displays an improved stability compared to the parent compound, while the stability of the conjugates is strongly influenced by the self-immolative moiety. Cathepsin B cleavage assays revealed that modifications in the linker lead to different drug release profiles. Antiproliferative effects of Arg-Gly-Asp (RGD)-cryptophycin conjugates were evaluated on M21 and M21-L human melanoma cell lines. The low nanomolar in vitro activity of the novel conjugates was associated with inferior selectivity for cell lines with different integrin $\alpha_{v} \beta_{3}$ expression levels. To elucidate the drug delivery process, cryptophycin was replaced by an infrared dye and the obtained conjugates were studied by confocal microscopy.
\end{abstract}

Keywords: antitumor agents; small molecule-drug conjugates; drug delivery; RGD peptides

\section{Introduction}

The selective delivery of cytotoxic drugs to tumors is a promising approach to overcome the drawbacks of traditional chemotherapy, such as limited efficacy and increased systemic toxicity [1]. Several antibody-drug conjugates (ADCs) and small molecule-drug conjugates (SMDCs) have been developed to increase the therapeutic index of cytotoxic agents by conjugating them to a delivery vehicle (i.e., antibody or small molecule) specifically binding to its target antigen present on the tumor 
cell surface [2-4]. Many of them are at various stages of clinical and preclinical development, and four ADCs (Adcetris ${ }^{\circledR}, \operatorname{Kadcyla}^{\circledR}$, Mylotarg $^{\circledR}$, and Besponsa ${ }^{\circledR}$ ) have been approved for cancer treatment [5]. Despite the significant success of ADCs, several limitations, like an unfavorable pharmacokinetic profile (low tissue diffusion and low tumor accumulation), immunogenicity, and high manufacturing costs, still need to be addressed [6]. Due to their smaller size, SMDCs have emerged as good alternatives for ADCs. In this case, the straightforward chemical synthesis and easier purification of SMDCs significantly reduces the production costs and allows an extensive hit to lead optimization. Moreover, SMDCs exhibit improved tumor penetration and do not trigger an immune response. However, because of their faster plasma clearance that allows reduced off-target tissue exposure, more frequent dosing may be required $[7,8]$.

Cryptophycins are a family of 16-membered macrocyclic depsipeptides, first isolated from cyanobacteria Nostoc sp. in 1990 [9]. This class of compounds is able to arrest the cell cycle in the $\mathrm{G}_{2} / \mathrm{M}$ phase by inhibition of microtubule polymerization at substoichiometric concentrations and by depolymerization of microtubules $[10,11]$, resulting in picomolar antiproliferative potency in vitro. Moreover, cryptophycins are poor substrates for P-glycoprotein (P-gp)-mediated transport, leading to retained activity against multidrug-resistant (MDR) cells [12]. The synthetic analogue, cryptophycin-52 (LY355703, 2, Figure 1) was developed as a potential clinical candidate but failed to exhibit significant response and showed unacceptable levels of neurotoxicity at the administered doses for the treatment of non-small cell lung cancer and platinum-resistant ovarian cancer $[13,14]$. Further investigations were not only focused on the development of functionalized cryptophycin analogues [15-17], but also on the conjugation of cryptophycin to tumor-homing peptides [18,19] and antibodies [20-22].
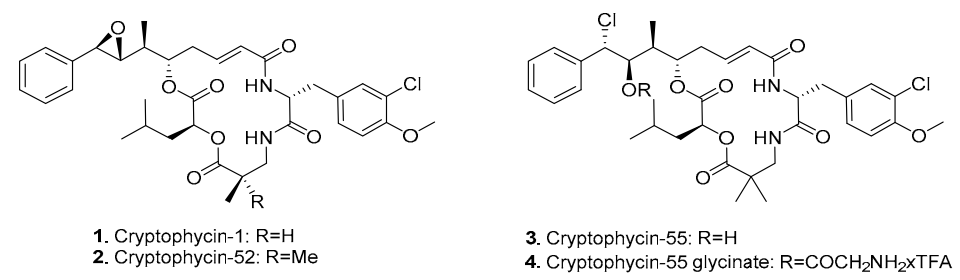

Figure 1. Chemical structure of cryptophycin derivatives.

Among the various functionalized cryptophycin derivatives, the chlorohydrin analogue of cryptophycin-52 (cryptophycin-55, 3, Figure 1) proved to be more active but less stable compared to the parent compound, while the glycinate ester of the chlorohydrin (4, Figure 1) displays both chemical stability and comparable or superior in vivo activity against solid tumors of mouse and human origin [23]. The free amino group of the glycinate provides a suitable attachment site for conjugation to delivery vehicles across a carbamate or amide bond formation. We have previously reported the application of cryptophycin-55 glycinate (Cry-55gly) for the development of tumor targeting ADCs [24] and SMDCs [25,26]. The conjugation of this payload to other targeting moieties is of considerable interest.

Integrins, a family of 24 heterodimeric transmembrane glycoproteins composed of 18 different $\alpha$ subunits and $8 \beta$ subunits, became widely studied targets in anticancer therapy due to their involvement in many steps of tumor growth [27]. The integrin $\alpha_{v} \beta_{3}$ is highly abundant in several human cancer cells (including melanoma, glioblastoma, prostate, pancreatic, breast cancer); it is overexpressed on the endothelial cells of tumor neovasculature, and it is involved in cancer progression and metastasis [28-30]. Integrin $\alpha_{\mathrm{v}} \beta_{3}$ recognizes its endogenous ligands by the tripeptide Arg-Gly-Asp (RGD) sequence [31]. Consequently, a large number of linear and cyclic RGD containing peptides and peptidomimetics have been developed with high binding affinity to the receptor [32-34]. Cilengitide, $c(\operatorname{RGDf}(\mathrm{NMe}) \mathrm{V})$, evolved as a highly active and selective ligand from structure-activity relationship studies utilizing the concept of conformation-dependent recognition. However, it failed in clinical phase III as anti-angiogenic agent for glioblastoma treatment [35]. Based on the fact that replacement of Val to Lys does not affect receptor binding and Lys can be used as a chemical handle to attach 
different entities, the functionalized cyclic pentapeptide $c$ (RGDfK) is broadly applied as carrier for imaging [36,37] and pharmacodelivery [38-41] applications.

We have previously prepared an azido-functionalized cryptophycin derivative that was conjugated to a modified $c$ (RGDfK) peptide across a non-cleavable triazole ring. The resulting conjugate showed an inferior cytotoxicity compared to the parent drug due to the stability of the linkage between the cytotoxin and the RGD ligand which did not allow the release of the free drug. Moreover, we have reported that a fluorescent cryptophycin-RGD conjugate undergoes fast endocytosis and shows colocalization with the lysosomes of human tumor cells [18]. For these reasons, conjugates with lysosomally cleavable linkers represent an excellent potential to ensure increased antitumor activity.

\section{Materials and Methods}

\subsection{Synthesis of Cryptophycin Conjugates}

Synthesis of Alkynyl-PEG5-Val-Cit-PABC-Cry-55gly (7): Cryptophycin-55 glycinate (Cry-55gly, 4) was synthesized as previously described [25]. Here, 4 (5 mg, $6.5 \mu \mathrm{mol}, 1 \mathrm{eq})$ and 5 (16 mg, $19.2 \mu \mathrm{mol}, 3 \mathrm{eq})$ were dissolved in anhydrous $N, N$-dimethylformamide (DMF) $(500 \mu \mathrm{L})$ under argon. $N, N$-diisopropylethylamine (DIPEA) $(5 \mu \mathrm{L}, 29.2 \mu \mathrm{mol}, 4.5 \mathrm{eq})$ was added and the mixture was stirred for $4 \mathrm{~h}$ at room temperature (RT), followed by reversed-phase high-performance liquid chromatography (RP-HPLC) purification (method M2/b, see Supplementary Material) to yield 7 as a colorless solid (6.0 mg, 63\%). Liquid Chromatography-Mass Spectrometry (LC-MS): $t_{\mathrm{R}}=10.28 \mathrm{~min},>99 \%$ purity $(\lambda=220 \mathrm{~nm}), m / z$ calcd for $\left[\mathrm{C}_{71} \mathrm{H}_{100} \mathrm{Cl}_{2} \mathrm{~N}_{8} \mathrm{O}_{20}\right]^{2+}: 727.32[\mathrm{M}+2 \mathrm{H}]^{2+}$, found: 727.34 .

Synthesis of Alkynyl-PEG5-Val-Cit-Gly-Pro-Cry-55gly (8): Here, 4 (4 mg, $5.25 \mu \mathrm{mol}, 1 \mathrm{eq})$, 6 (16 mg, $21 \mu \mathrm{mol}, 4 \mathrm{eq}$ ), benzotriazol-1-yloxy)tripyrrolidinophosphonium hexafluorophosphate (PyBOP) (11 mg, $21 \mu \mathrm{mol}, 4 \mathrm{eq})$, and $\mathrm{N}$-hydroxybenzotriazole (HOBt) $(4 \mathrm{mg}, 24 \mu \mathrm{mol}, 4.5 \mathrm{eq}$ ) were dissolved in anhydrous DMF $(700 \mu \mathrm{L})$ under argon. DIPEA $(4 \mu \mathrm{L}, 24 \mu \mathrm{mol}, 4.5 \mathrm{eq})$ was added and the mixture was stirred for $4 \mathrm{~h}$ at RT, followed by RP-HPLC purification (method M2/b) to yield 8 as a colorless solid $(6.0 \mathrm{mg}, 78 \%)$. LC-MS: $t_{\mathrm{R}}=10.05 \mathrm{~min},>99 \%$ purity $(\lambda=220 \mathrm{~nm}), \mathrm{m} / z$ calcd for $\left[\mathrm{C}_{70} \mathrm{H}_{102} \mathrm{Cl}_{2} \mathrm{~N}_{9} \mathrm{O}_{20}\right]^{+}: 1458.66[\mathrm{M}+\mathrm{H}]^{+}$, found: $1458.69 ; m / z$ calcd for $\left[\mathrm{C}_{70} \mathrm{H}_{103} \mathrm{Cl}_{2} \mathrm{~N}_{9} \mathrm{O}_{20}\right]^{2+}: 729.83$ $[\mathrm{M}+2 \mathrm{H}]^{2+}$, found: 729.85 .

Synthesis of $c$ (RGDfK)-PEG5-Val-Cit-PABC-Cry-55gly (10): Here, 7 (3.5 mg, $2.4 \mu \mathrm{mol}, 1$ eq), 9 (1.9 mg, $2.6 \mu \mathrm{mol}, 1.1 \mathrm{eq}), \mathrm{CuSO}_{4} \cdot 5 \mathrm{H}_{2} \mathrm{O}(0.3 \mathrm{mg}, 1.2 \mu \mathrm{mol}, 0.5 \mathrm{eq})$, and sodium ascorbate $(0.29 \mathrm{mg}$, $1.4 \mu \mathrm{mol}, 0.6 \mathrm{eq})$ were dissolved in $\mathrm{DMF} / \mathrm{H}_{2} \mathrm{O}\left(1: 1,200 \mu \mathrm{L}\right.$, degassed) and stirred for $24 \mathrm{~h}$ at $35^{\circ} \mathrm{C}$, followed by RP-HPLC purification (method M2/b) to yield $\mathbf{1 0}$ as a colorless solid (3.3 $\mathrm{mg}, 64 \%$ ). LC-MS: $t_{\mathrm{R}}=7.77 \mathrm{~min},>99 \%$ purity $(\lambda=220 \mathrm{~nm}), \mathrm{m} / z$ calcd for $\left[\mathrm{C}_{101} \mathrm{H}_{144} \mathrm{Cl}_{2} \mathrm{~N}_{20} \mathrm{O}_{28}\right]^{2+}: 1077.49$ $[\mathrm{M}+2 \mathrm{H}]^{2+}$, found: $1077.52 ; \mathrm{m} / z$ calcd for $\left[\mathrm{C}_{101} \mathrm{H}_{145} \mathrm{Cl}_{2} \mathrm{~N}_{20} \mathrm{O}_{28}\right]^{3+}: 718.66[\mathrm{M}+3 \mathrm{H}]^{3+}$, found: 718.68. High Resolution Mass Spectrometry, Electrospray Ionization Mass Spectrometry (HRMS (ESI-MS)): $m / z$ calcd for $\left[\mathrm{C}_{101} \mathrm{H}_{144} \mathrm{Cl}_{2} \mathrm{~N}_{20} \mathrm{O}_{28}\right]^{2+}: 1077.4913[\mathrm{M}+2 \mathrm{H}]^{2+}$, found: $1077.4867 ; \mathrm{m} / z$ calcd for $\left[\mathrm{C}_{101} \mathrm{H}_{145} \mathrm{Cl}_{2} \mathrm{~N}_{20} \mathrm{O}_{28}\right]^{3+}: 718.6633[\mathrm{M}+3 \mathrm{H}]^{3+}$, found: 718.6595 .

Synthesis of $c$ (RGDfK)-PEG5-Val-Cit-Gly-Pro-Cry-55gly (11): Here, 8 ( $3.5 \mathrm{mg}, 2.4 \mu \mathrm{mol}, 1 \mathrm{eq}$ ), 9 (1.8 mg, $2.6 \mu \mathrm{mol}, 1.1 \mathrm{eq}), \mathrm{CuSO}_{4} \cdot 5 \mathrm{H}_{2} \mathrm{O}(0.3 \mathrm{mg}, 1.2 \mu \mathrm{mol}, 0.5 \mathrm{eq})$, and sodium ascorbate $(0.29 \mathrm{mg}$, $1.4 \mu \mathrm{mol}, 0.6 \mathrm{eq})$ were dissolved in $\mathrm{DMF} / \mathrm{H}_{2} \mathrm{O}\left(1: 1,200 \mu \mathrm{L}\right.$, degassed) and stirred for $24 \mathrm{~h}$ at $35^{\circ} \mathrm{C}$, followed by RP-HPLC purification (method M2/b) to yield 11 as a colorless solid (2.80 $\mathrm{mg}, 54 \%$ ). LC-MS: $t_{\mathrm{R}}=7.31 \mathrm{~min},>99 \%$ purity $(\lambda=220 \mathrm{~nm}), m / z$ calcd for $\left[\mathrm{C}_{100} \mathrm{H}_{147} \mathrm{Cl}_{2} \mathrm{~N}_{21} \mathrm{O}_{28}\right]^{2+}: 1080.00[\mathrm{M}+$ $2 \mathrm{H}]^{2+}$, found: $1080.02 ; \mathrm{m} / z$ calcd for $\left[\mathrm{C}_{100} \mathrm{H}_{148} \mathrm{Cl}_{2} \mathrm{~N}_{21} \mathrm{O}_{28}\right]^{3+}: 720.34[\mathrm{M}+3 \mathrm{H}]^{3+}$, found: $720.34 ;$ HRMS (ESI-MS): $m / z$ calcd for $\left[\mathrm{C}_{100} \mathrm{H}_{147} \mathrm{Cl}_{2} \mathrm{~N}_{21} \mathrm{O}_{28}\right]^{2+}: 1080.0045[\mathrm{M}+2 \mathrm{H}]^{2+}$, found: $1080.0126 ; m / z$ calcd for $\left[\mathrm{C}_{100} \mathrm{H}_{148} \mathrm{Cl}_{2} \mathrm{~N}_{21} \mathrm{O}_{28}\right]^{3+}: 720.3388[\mathrm{M}+3 \mathrm{H}]^{3+}$, found: 720.3428 .

\subsection{Integrin Binding Assay}

An ELISA-like assay using isolated integrins was performed to determine binding affinity [34]. Cilengitide $\left(\alpha_{\mathrm{v}} \beta_{3}: I C_{50}=0.54 \mathrm{nM}\right)$ was used as internal reference. All wells of flat-bottom 96-well 
Immuno Plates (BRAND GmbH \& Co. KG, Wertheim, Germany) were coated overnight at $4{ }^{\circ} \mathrm{C}$ with $100 \mu \mathrm{L}$ human vitronectin solution $(1.0 \mu \mathrm{g} / \mathrm{mL}$, \#2349-VN-100, R\&D Systems, Minneapolis, MI, USA) in carbonate buffer (15 mM Na $2 \mathrm{CO}_{3}, 35 \mathrm{mM} \mathrm{NaHCO}, \mathrm{pH}$ 9.6). Each well was then washed with phosphate-buffered saline/Tween20 (PBS-T-buffer, $137 \mathrm{mM} \mathrm{NaCl}, 2.7 \mathrm{mM} \mathrm{KCl}, 10 \mathrm{mM} \mathrm{Na} 2 \mathrm{HPO}_{4}$, $2 \mathrm{mM} \mathrm{KH} \mathrm{PO}_{4}, 0.01 \%$ Tween20, pH 7.4; $3 \times 200 \mu \mathrm{L}$ ) and blocked for $1 \mathrm{~h}$ at room temperature with TS-B-buffer (Tris-saline/bovine serum albumin (BSA) buffer, $150 \mu \mathrm{L} /$ well, $20 \mathrm{mM}$ Tris-HCl, $150 \mathrm{mM}$ $\mathrm{NaCl}, 1 \mathrm{mM} \mathrm{CaCl}_{2}, 1 \mathrm{mM} \mathrm{MgCl}$, $1 \mathrm{mM} \mathrm{MnCl}_{2}, \mathrm{pH} 7.5,1 \%$ BSA). A dilution series of the compound and internal standard were prepared in TS-B-buffer. After washing the assay plate with PBS-T $(3 \times 200 \mu \mathrm{L}), 50 \mu \mathrm{L}$ of the dilution series were transferred to each well, for negative control $100 \mu \mathrm{L}$ TS-B-buffer and for positive control $50 \mu \mathrm{L}$ TS-B-buffer were used. Then, $50 \mu \mathrm{L}$ of human $\alpha_{\mathrm{v}} \beta_{3}$ integrin $(2.0 \mu \mathrm{g} / \mathrm{mL}$, \#3050-AV-050, R\&D) in TS-B-buffer were transferred to wells (except wells containing the negative control) and incubated for $1 \mathrm{~h}$ at RT. After washing the plates $(3 \times 200 \mu \mathrm{L})$ with PBS-T buffer, $100 \mu \mathrm{L}$ primary antibody mouse anti-human CD51/61 (2.0 $\mu \mathrm{g} / \mathrm{mL}$, \#555504, BD Biosciences, San Jose, CA, USA) were added to all wells and incubated for $1 \mathrm{~h}$ at RT. The plate was washed $(3 \times 200 \mu \mathrm{L})$ with PBS-T buffer and $100 \mu \mathrm{L}$ of secondary, peroxidase linked antibody (anti-mouse IgG-POD goat, $1.0 \mu \mathrm{g} / \mathrm{mL}$, \#A441, Sigma Aldrich, St. Louis, MO, USA) were added to all wells and incubated for $1 \mathrm{~h}$ at RT. The plate was washed $(3 \times 200 \mu \mathrm{L})$ with PBS-T buffer and $50 \mu \mathrm{L}$ SeramunBlau (SeramunBlau fast S-001-1-TMB, Seramun Diagnostica GmbH, Heidesee, Germany) were added to all wells. The development was stopped with $3 \mathrm{M} \mathrm{H}_{2} \mathrm{SO}_{4}(50 \mu \mathrm{L} /$ well $)$ when a blue color gradient was visible $(\sim 1 \mathrm{~min})$. The absorbance was measured with a plate reader at $450 \mathrm{nM}$ (Tecan, Infinite M200, Zürich, Switzerland). The resulting curves were analyzed with OriginPro 2017G (OriginLab Corporation, Northampton, MA, USA) with the inflection point describing the $I C_{50}$ value. Each compound was tested twice in triplicates and referenced to the internal standard.

\subsection{Plasma Metabolic Stability Assay}

The sample preparation and the metabolic analysis of the conjugates was carried out similarly to a previously described method [42]. In a 96-well plate, the stock solutions ( $3 \mathrm{mM}$ in dimethyl sulfoxide (DMSO)) of the conjugates and the control compound were diluted with $250 \mu \mathrm{L}$ of plasma (pooled heparinized mouse ICR/CD1 M plasma \#08 or human plasma \#MPLLIHP-M, \#BHR1003077, BioreclamationIVT, Westbury, NY, USA) to give a 3- $\mu \mathrm{M}$ concentration and incubated at $37^{\circ} \mathrm{C}$. At each sampling time an aliquot of $30 \mu \mathrm{L}$ was transferred into a 96-deep-well plate and the reaction was stopped with $120 \mu \mathrm{L}$ of acetonitrile (ACN) containing $0.1 \% \mathrm{HCOOH}$ and $400 \mathrm{ng} / \mathrm{mL}$ of warfarin as internal standard (IS). This mixture was centrifuged at $1100 \times g$ for $30 \mathrm{~min}$ at $4{ }^{\circ} \mathrm{C}$ and $50 \mu \mathrm{L}$ of supernatants were transferred into a clean 96-deep-well plate and diluted with $50 \mu \mathrm{L}$ of $0.1 \% \mathrm{HCOOH}$ in water. Samples were stored at $-80{ }^{\circ} \mathrm{C}$ prior to UPLC-HRMS analysis (see Supplementary Materials). The stability was determined based on the disappearance of the test compound as a function of incubation time, using area ratios (analyte peak area vs internal standard peak area). The elimination constant $\mathrm{k}$ was calculated by plotting mean disappearance values on a semi-logarithmic scale and fitting with a best fit linear regression using Microsoft Excel. The half-life $\left(t_{1 / 2}\right)$ expressed in hours was determined using equation: $t_{1 / 2}=\ln 2 /(-k)$. Full metabolite analysis was done using Compound Discoverer $^{\mathrm{TM}} 2.1$ (Thermo Fisher Scientific, Waltham, MA, USA) software.

\subsection{Cathepsin B Cleavage Assay}

L-cysteine (\#C8152, Sigma Aldrich) was dissolved in acetate buffer/ethylenediaminetetraacetic acid (EDTA) $1 \mathrm{mM} \mathrm{pH} 5.5$ to get a solution with a final concentration of L-cysteine of $28 \mathrm{mM}$. This solution was used to dilute an aliquot of cathepsin B (bovine spleen cathepsin B, \#C6286, Sigma Aldrich) to $1.11 \mathrm{U} / \mathrm{mL}$. Sample containing cathepsin B was pre-incubated at $37^{\circ} \mathrm{C}$ for 15 min and then split into $45-\mu \mathrm{L}$ aliquots in Eppendorf tubes, two replicates for each incubation time. Aliquots of $5 \mu \mathrm{L}$ of $50 \mu \mathrm{M}$ solutions of the substrates prepared in $\mathrm{MeOH} / \mathrm{H}_{2} \mathrm{O}(50 / 50)$ were added to each tube, to get a final concentration of $5 \mu \mathrm{M}$. Tubes corresponding to $t=0 \mathrm{~min}$ contained $100 \mu \mathrm{L}$ of $1 \%$ 
$\mathrm{HCOOH}$ in $\mathrm{MeOH}$ and were put in an ice bath to stop the reaction. All the other tubes were incubated at $37^{\circ} \mathrm{C}$ in an oscillating thermostatic bath and reaction was stopped at the following incubation times: $0.25,0.5,1,2,4$, and $6 \mathrm{~h}$, as described for $t=0$ min samples. Samples were centrifuged for $10 \mathrm{~min}$ at $14,000 \mathrm{rpm}$ at $4{ }^{\circ} \mathrm{C}$ and filtered with regenerated cellulose syringe filters prior to injection in the HPLC-MS system (see Supplementary Materials). Control solutions of each compound (5 $\mu \mathrm{M}$ in acetate buffer $\mathrm{pH} 5.5 /$ EDTA $1 \mathrm{mM}$ /L-cysteine $28 \mathrm{mM}$ ) were also prepared and incubated up to $6 \mathrm{~h}$ at $37^{\circ} \mathrm{C}$ in the absence of the enzyme to check substrate stability at the incubation conditions. Substrates and possible metabolites were quantified based on calibration curves prepared in acetate buffer/EDTA/L-cysteine.

\subsection{Degradation in Human Liver Lysosomal Homogenate}

Pooled human liver lysosomes (\#H0610.L) at $2.5 \mathrm{mg}$ protein/mL, cathepsin B activity $96.5 \pm 3.96$ units/mg protein were purchased from Sekisui XenoTech (Kansas City, KS, USA).

Experiments were performed based on the method described previously [43], with some modifications. Conjugates and control compound (Bz-FVR-p-nitroanilide, \#B7632, Sigma Aldrich) were diluted in $0.2 \mathrm{M}$ citrate phosphate buffer, $\mathrm{pH} 5.5$, containing $0.1 \%(v / v \%)$ Triton X-100, $5 \mathrm{mM}$ reduced glutathione, $1 \mathrm{mM}$ EDTA, and human liver lysosomes $(1.5 \mathrm{mg}$ protein $/ \mathrm{mL})$ to give a $3 \mu \mathrm{M}$ final concentration. At each time point $(0,0.5,1$, and $2 \mathrm{~h})$ an aliquot of $30 \mu \mathrm{L}$ was transferred into a new 96-deep-well plate and the reaction was stopped with $120 \mu \mathrm{L}$ of ACN containing $0.1 \% \mathrm{HCOOH}$ and $0.4 \mu \mathrm{g} / \mathrm{mL}$ of warfarin as internal standard (IS). At the end of the assay, the plate was centrifuged at $1100 \times g$ for $30 \mathrm{~min}$ at $4{ }^{\circ} \mathrm{C}$ and $50 \mu \mathrm{L}$ of the supernatant were transferred into a new 96-deep-well plate. The sample was diluted with $50 \mu \mathrm{L}$ of mixture of $\mathrm{ACN} / \mathrm{H}_{2} \mathrm{O} / \mathrm{HCOOH}=20 / 80 / 0.1$. Samples were stored at $-80^{\circ} \mathrm{C}$ prior to UPLC-HRMS analysis (see Supplementary Materials).

\subsection{In Vitro Cytotoxicity Assay}

The human melanoma M21 and M21-L cells were kindly provided by Dr. David Cheresh and The Scripps Research Institute (La Jolla, CA, USA). Cells were cultured in RPMI 1640 supplemented with $10 \%$ fetal bovine serum (FBS), 1\% L-glutamine and 1\% Penicillin/Streptomycin in a humidified incubator at $37^{\circ} \mathrm{C}$ and $5 \% \mathrm{CO}_{2}$.

Cell viability was quantified by 3-(4,5-dimethylthiazol-2-yl)-2,5-diphenyltetrazolium bromide (MTT) assay. Cells were plated at a density of 3000 cells / well (Nunc ${ }^{\circledR}$ MicroWell ${ }^{\circledR}$ flat-bottom 96-well plate, Thermo Fisher Scientific) and incubated overnight to allow adherence. The following day, cells were treated with serial dilutions of each compound or $0.1 \%$ DMSO as control. After $2 \mathrm{~h}$ of incubation, cells were centrifuged at $1200 \mathrm{rpm}$ for $5 \mathrm{~min}$; supernatant containing the compounds was removed and replaced with fresh medium. Cells were further incubated for $70 \mathrm{~h}$ as described above, and at the end of treatment, $5 \mu \mathrm{L}$ of MTT $\left(5 \mathrm{mg} / \mathrm{mL}\right.$ in deionized $\mathrm{H}_{2} \mathrm{O}$, \#M5655, Sigma Aldrich) were added to each well and the cells incubated for another $2 \mathrm{~h}$. Finally, $100 \mu \mathrm{L}$ of lysis buffer (10\% SDS, $10 \mathrm{mM} \mathrm{HCl})$ were added, and cells were placed in the incubator overnight for the formazan crystal solubilization. Absorbance at $540 \mathrm{~nm}$ was measured using FLUOstar Omega (BMG Labtech, Ortenberg, Germany) instrument and the growth inhibition ratio was calculated. Blank controls detecting cell-free media absorbance were performed in parallel. Three experimental replicates were used. The half-maximal inhibitory concentration values $\left(I C_{50}\right)$ were obtained from viability curves by fitting data to the four-parameter logistic equation using GraphPad Prism 6 (GraphPad Software, San Diego, CA, USA). The cell viability was expressed as percentage relative to the respective control conditions.

\subsection{Flow Cytometry Analysis}

The M21 and M21-L cells were plated at a density of 80,000 cells/mL/well in a 12-well plate and incubated overnight at $37^{\circ} \mathrm{C}$. The next day, cells were incubated with LM142 mouse anti-human integrin $\alpha_{\mathrm{V}}$ monoclonal antibody (\#MAB1978, Merck Millipore, Merck KGaA, Darmstadt, Germany, 1:500 dilution) or with mouse anti-human CD51/CD61 (\#555504, BD Biosciences, San Jose, CA, USA) at 
$1 \mu \mathrm{g} / \mathrm{mL}$ for $15 \mathrm{~min}$ on ice. Subsequently, cells were washed with PBS and incubated with anti-mouse IgG-Alexa Fluor 488 (\#A-11029, Thermo Fisher Scientific) at $8.3 \mu \mathrm{g} / \mathrm{mL}$ for $15 \mathrm{~min}$ on ice. Finally, cells were washed with PBS, and samples were acquired using BD FACSCalibur ${ }^{\mathrm{TM}}$ flow cytometer and analyzed using FlowJo software v.10 (FlowJo LCC, Ashland, OR, USA). Anti-mouse IgG antibody was used as the negative isotope control.

\subsection{Confocal Microscopy}

The real-time internalization of the fluorescently labeled compounds $\mathbf{1 5}$ and $\mathbf{1 6}$ was acquired using a ZEISS LSM 880 confocal microscope (Carl Zeiss AG, Oberkochen, Germany) coupled with an environmental chamber allowing a $37^{\circ} \mathrm{C}, 5 \% \mathrm{CO}_{2}$ atmosphere. The M21 and M21-L human melanoma cells were grown overnight in eight-well chambered slides (Nunc ${ }^{\circledR}$ Lab-Tek ${ }^{\circledR}$, Sigma Aldrich) previously coated with poly-D-Lysine $(10 \mu \mathrm{g} / \mathrm{mL}$, Sigma Aldrich). The fluorescently labeled conjugates were diluted in phenol red-free media to $1 \mu \mathrm{M}(0.1 \% \mathrm{DMSO})$ and warmed up to $37^{\circ} \mathrm{C}$. Picture acquisition was made using a $40 \times$ water immersion objective and started shortly after the solutions were added to the cells, a frame was made every $30 \mathrm{~s}$ for a total of 60 frames. Brightfield was used to distinguish the cell's structures.

\section{Results and Discussion}

\subsection{Design and Synthesis}

The RGD-cryptophycin conjugates consist of the highly cytotoxic payload, cryptophycin-55 glycinate, and $c$ (RGDfK) peptide connected through the protease-cleavable Val-Cit dipeptide linker, which is extensively used in the ADC field [44]. This peptide-based linker displays an excellent balance between high stability in circulation and rapid intracellular cleavage in the presence of lysosomal proteases, mainly cathepsin B [45] and other cysteine cathepsins [46,47]. In order to achieve efficient release of the cytotoxin in an active form, two different self-immolative spacers were inserted between the drug and the cleavage site: the para-aminobenzyloxycarbonyl (PABC) spacer, which undergoes 1,6-elimination, or the Gly-Pro dipeptide unit, which was designed to decompose by diketopiperazine formation [48,49]. A polyethylene glycol (PEG5) spacer was introduced between the integrin ligand and the cleavage site to improve water solubility of the conjugate.

The RGD-cryptophycin conjugates $\mathbf{1 0}$ and $\mathbf{1 1}$ were prepared as shown in Scheme 1. For the synthesis of cleavable linker 5, Val-Cit-PABOH was reacted with an alkyne-functionalized polyethylene glycol spacer (19), followed by activation with bis(4-nitrophenyl) carbonate giving the desired compound (Scheme S2). The cleavable linker 6 was synthetized by standard Fmoc/ ${ }^{t} \mathrm{Bu}$ solid-phase peptide synthesis (SPPS) on 2-chlorotrityl chloride resin. The Val-Cit-Gly-Pro tetrapeptide was elongated by the coupling of polyethylene glycol spacer (19) containing alkyne moiety on the solid support. After cleavage from the resin and purification by preparative HPLC, the peptide linker was obtained in good yield (32\%) and excellent purity. Linkers 5 and $\mathbf{6}$ were conjugated to cryptophycin-55 glycinate (4), which was synthetized as described previously [25], affording the corresponding linker-drugs 7 and 8 in good yields (63-78\%). The lysine residue of $c$ (RGDfK) peptide was modified with 3-azidopropanoic acid allowing the conjugation of the ligand 9 to the linker-drugs 7 and 8 by $\mathrm{Cu}(\mathrm{I})$ catalyzed azide-alkyne cycloaddition (CuAAC click reaction). The resulting final conjugates $\mathbf{1 0}$ and $\mathbf{1 1}$ were purified by preparative HPLC and characterized by analytical HPLC and HRMS.

\subsection{Integrin Binding Affinity}

To investigate how the conjugation affects the binding properties of our ligand, the binding affinity of conjugates $\mathbf{1 0}$ and $\mathbf{1 1}$ was compared to those of free ligands ( $\mathbf{9}$ and cilengitide) using a competitive ELISA-based assay (Figure 2A). Integrin binding assays were performed by incubation of immobilized vitronectin with increasing concentrations of the test compound $\left(10^{-5}-10^{-12} \mathrm{M}\right)$ in 
the presence of soluble human $\alpha_{\mathrm{v}} \beta_{3}$ integrin. Functionalization of ligand 9 has a negligible effect on receptor binding $\left(I C_{50}: 0.71 \mathrm{nM}\right.$ vs cilengitide $\left.I C_{50}: 0.54 \mathrm{nM}\right)$ [34]. Despite the increased size and steric bulkiness, conjugates $\mathbf{1 0}$ and $\mathbf{1 1}$ retained strong binding affinity to the receptor with $I C_{50}$ values in the low nanomolar range ( $8.3 \mathrm{nM}$ and $12.7 \mathrm{nM}$, respectively).

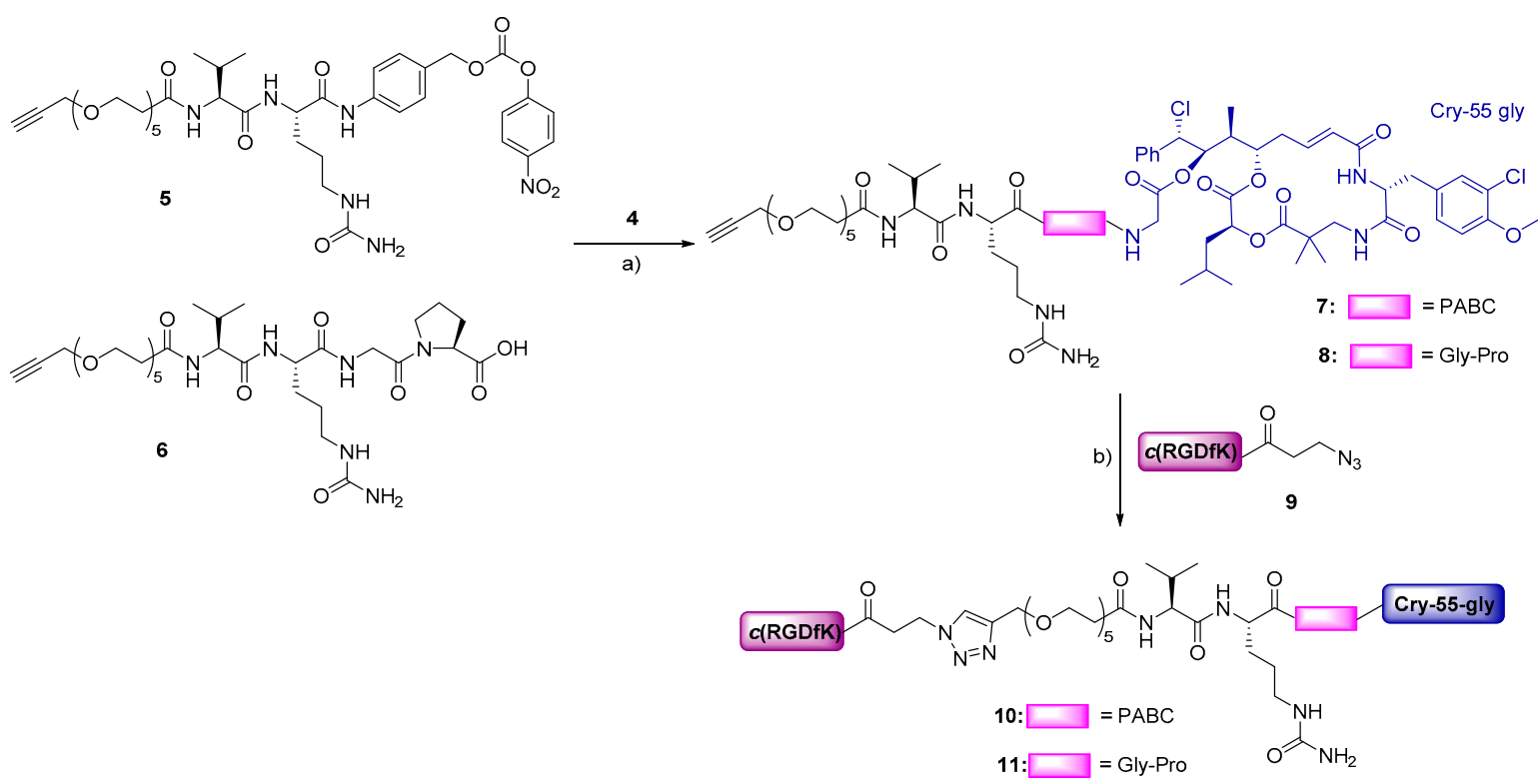

Scheme 1. Synthesis of conjugates 10 and 11. Reagents and conditions: (a) 5 (1.1 eq), DIPEA (3 eq), DMF, RT, 5 h or 6 (3 eq), PyBOP (3 eq), HOBt (3.5 eq), DIPEA (3.5 eq), DMF, RT, 5 h; (b) 9 (1.1 eq), $\mathrm{CuSO}_{4} \cdot 5 \mathrm{H}_{2} \mathrm{O}(0.5 \mathrm{eq})$, sodium ascorbate $(0.6 \mathrm{eq}), 1: 1 \mathrm{DMF} / \mathrm{H}_{2} \mathrm{O}, 35^{\circ} \mathrm{C}, 24 \mathrm{~h}$.

A.

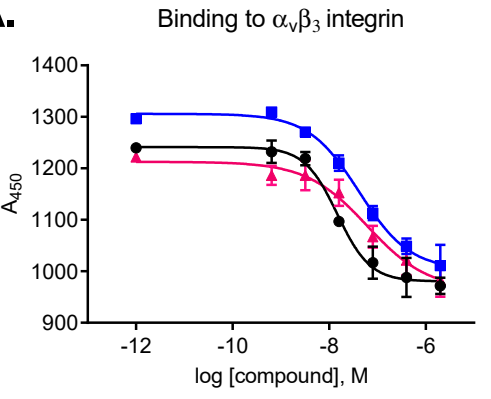

C.

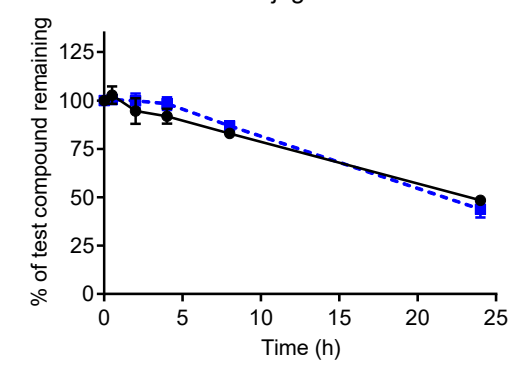

B.

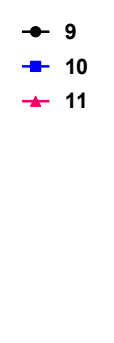

$\rightarrow$ Mouse

-ש. Human

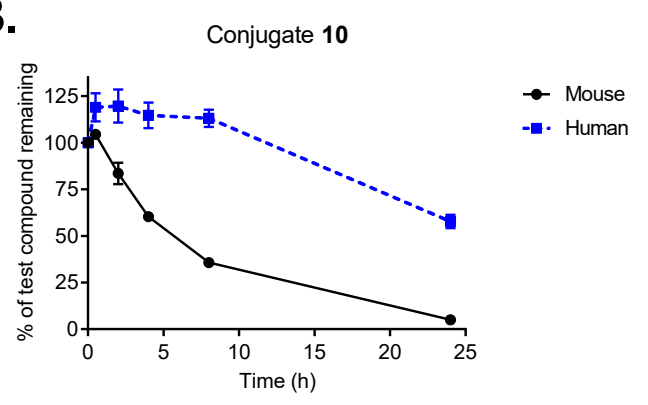

D. Metabolism of conjugate $\mathbf{1 0}$ in mouse plasma

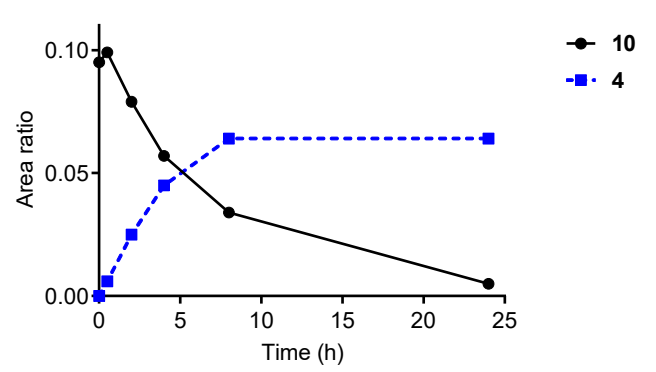

Figure 2. (A) Integrin $\alpha_{\mathrm{v}} \beta_{3}$ binding affinity of conjugates $\mathbf{1 0}$ and $\mathbf{1 1}$ compared to the free ligand (9). (B) Plasma stability of conjugate $\mathbf{1 0}$ in mouse and human plasma. (C) Plasma stability of conjugate 11 in mouse and human plasma. (D) Metabolism of conjugate $\mathbf{1 0}$ in mouse plasma and the release of cryptophycin-55 glycinate (4). Data points are averages of three experiments, error bars indicate SD. 


\subsection{Plasma Metabolic Stability}

Keeping in mind that our conjugates contain moieties susceptible for hydrolysis, and in vivo payload deactivating metabolism of antibody-cryptophycin conjugates was also reported [50], the in vitro plasma metabolic stability of cryptophycins and RGD-cryptophycin conjugates was assayed in human and mouse plasma.

Plasma metabolic stability studies demonstrated that our selected payload (cryptophycin- 55 glycinate, 4) shows markedly improved stability compared to the parent compound (cryptophycin-52, 2) in murine plasma and a good stability in human plasma over $24 \mathrm{~h}$ (Figure S1A,B). Cryptophycin-52 demonstrated significant metabolism in mouse plasma, including hydrolysis of the macrocycle and loss of units C and D (Figure S1C,D). The same metabolic pathway was proposed for an epoxide containing cryptophycin analog used as ADC payload [50]. In contrast, esterification of the chlorohydrin derivative with glycine was found to provide an enhanced protection of the macrocycle. Taking into account, that cryptophycin-55 glycinate was not affected by ester or amide hydrolysis, increases its potential to be an effective payload.

Conjugates 10 and 11 display good stability in human plasma, with half-lives of more than $24 \mathrm{~h}$ and $20 \mathrm{~h}$, respectively (Figure 2B,C). Interestingly, stability in mouse plasma was influenced by the type of self-immolative moiety, conjugate $\mathbf{1 1}$ containing the peptide-based Val-Cit-Gly-Pro linker displayed superior stability $\left(t_{1 / 2}=23 \mathrm{~h}\right)$ compared to conjugate 10 with the Val-Cit-PABC linker $\left(t_{1 / 2}=6 \mathrm{~h}\right)$. Metabolite identification revealed that the most relevant biotransformation, responsible for the lack of stability of conjugate $\mathbf{1 0}$ in mouse plasma, is the hydrolysis of the Val-Cit-PABC linker, resulting in the release of cryptophycin-55 glycinate as major metabolite (Figure 2D). The amide bond between the Cit and the PABC self-immolative moiety is known to be susceptible to enzymatic hydrolysis in mouse plasma [51]. Full metabolite analysis revealed additional minor metabolites of conjugate $\mathbf{1 0}$ in mouse plasma (Table S1, Figure S2).

Our results are consistent with previously published data, showing good stability of Val-Cit-PABC-containing conjugates in human plasma [45] and comparable mouse serum stability of SMDCs bearing the same linker [52]. Furthermore, conjugate 11 containing the Val-Cit-Gly-Pro peptidic linker has similar plasma stability as an octreotide-cryptophycin conjugate having the same linker [26].

\subsection{Drug Release by Cathepsin B and Degradation in Human Liver Lysosomes}

To confirm the susceptibility of the bioconjugates to enzymatic cleavage and prove efficient drug release, the cleavage of conjugates $\mathbf{1 0}$ and $\mathbf{1 1}$ was monitored in the presence of cathepsin $\mathrm{B}$ $(1 \mathrm{U} / \mathrm{mL})$ at $37^{\circ} \mathrm{C}$. As expected, conjugates $\mathbf{1 0}$ and $\mathbf{1 1}$ were rapidly cleaved upon incubation with the enzyme (Figure 3B). In case of conjugate 10, the enzymatic cleavage of Val-Cit linker resulted in 1,6-elimination of the PABC-spacer and the release of the highly active payload cryptophycin-55 glycinate (4) was observed within $15 \mathrm{~min}$ following incubation. These results are in agreement with previously reported studies of enzymatic drug release from SMDCs and ADCs containing the Val-Cit-PABC linker [45,53]. In contrast, the cathepsin B mediated linker cleavage of conjugate $\mathbf{1 1}$ led to the formation of Gly-Pro-Cry-55gly (12), which was not further metabolized to cryptophycin-55 glycinate under the test conditions. This indicates that the enzymatic activation is not followed by intramolecular cyclization and self-immolation of the Gly-Pro dipeptide (Figure 3A).

Although it was reported that prodrugs that contain the Gly-Pro dipeptide linked to paclitaxel via ester bond are able to efficiently release paclitaxel after incubation with plasmin for $3 \mathrm{~h} \mathrm{[54],} \mathrm{our} \mathrm{results}$ indicate that self-immolation by diketopiperazine formation does not take place when the Gly-Pro dipeptide is connected to the drug via amide bond. However, the cytotoxicity of metabolite $\mathbf{1 2}$ is still of high relevance for the biological activity of conjugate $\mathbf{1 1}$. 


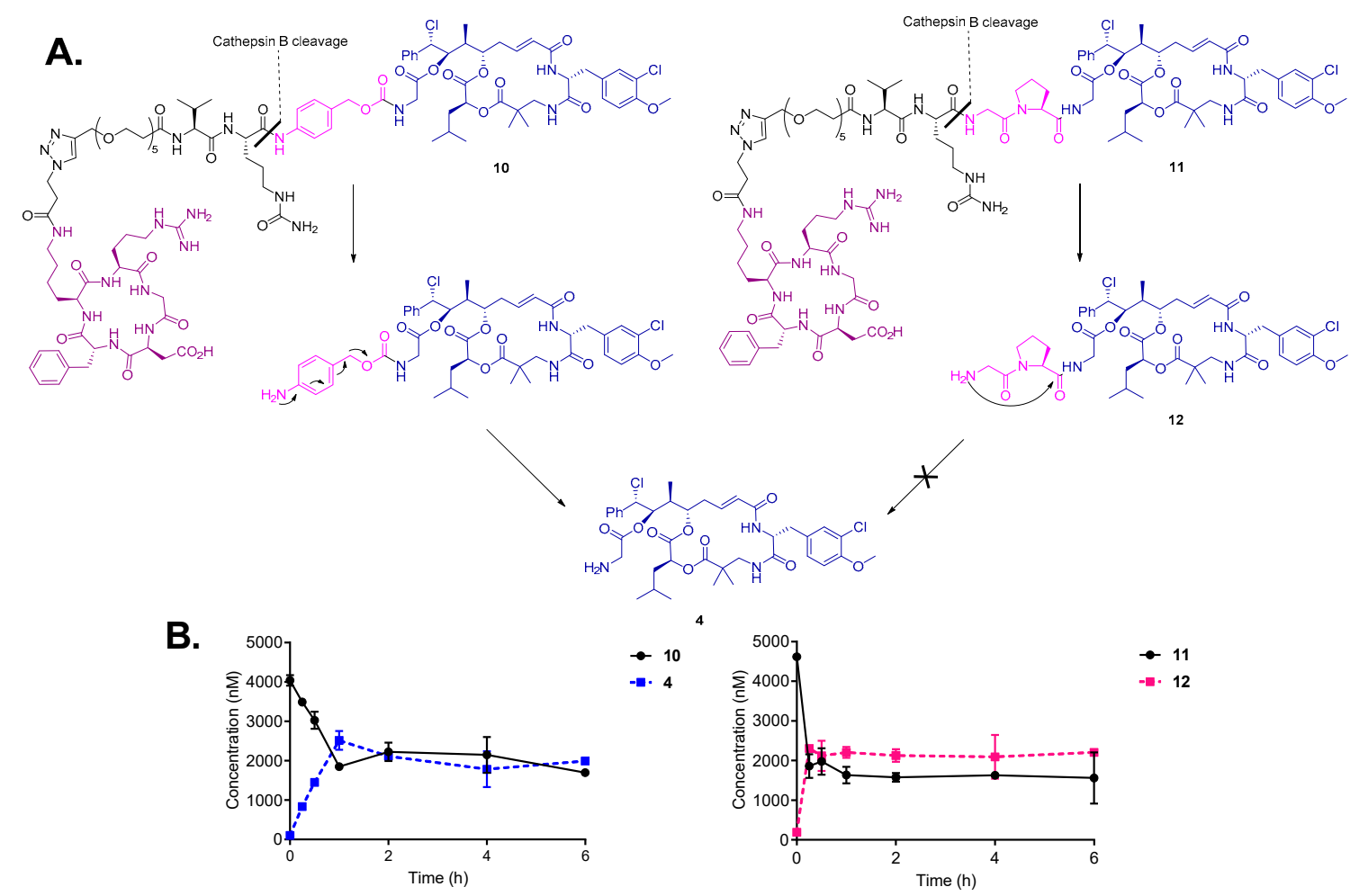

Figure 3. (A) Cleavage and self-immolation mechanism of conjugates $\mathbf{1 0}$ and $\mathbf{1 1}$ in the presence of cathepsin B enzyme. (B) Cleavage and metabolism of conjugate $\mathbf{1 0}$ (left) and $\mathbf{1 1}$ (right) upon incubation with cathepsin B enzyme.

In a similar experiment, incubation of conjugates $\mathbf{1 0}$ and $\mathbf{1 1}$ with human liver lysosomes confirmed the above presented metabolic pathway for each conjugate. Cryptophycin-55 glycinate was found to be released in the case of conjugate 10, while the formation of Gly-Pro-Cry-55gly metabolite was characteristic for conjugate 11, without further self-immolation step (Figures S3 and S4). Control experiments indicated that both conjugates are stable in the absence of enzyme or lysosomes. These experiments demonstrated efficient linker processing in the presence of cathepsin B and in the intracellular compartment. Additionally, the character of self-immolative spacer resulted in different drug release profiles.

\subsection{In Vitro Cytotoxicity Assay}

Having determined that the self-immolative moiety has a great impact on the intracellular activation of the RGD-cryptophycin conjugates, an MTT-based cell viability assay was used to evaluate the in vitro cytotoxicity of the payload 4, the drug-containing metabolite $\mathbf{1 2}$, and conjugates $\mathbf{1 0}$ and 11 (Table 1, Figure 4). The M21 and M21-L human melanoma cells were used to test in vitro the tumor-targeting potential of the novel conjugates $[55,56]$. The M21 cells overexpress $\alpha_{v} \beta_{3}$ integrin, while the M21-L, a stable variant of the wild type cell line, fails to express integrin $\alpha_{v}$, thus causing a lack of $\alpha_{v}$ integrin heterodimers $\left(\alpha_{v} \beta_{3}, \alpha_{v} \beta_{5}\right.$, and $\left.\alpha_{v} \beta_{6}\right)$. The integrin $\alpha_{v}$ and $\alpha_{v} \beta_{3}$ expression was confirmed by flow cytometry analysis (Figure S5).

Cryptophycin- 55 glycinate displayed high in vitro potency against both cell lines with $I C_{50}$ values in the sub nanomolar range. However, the parent compound, cryptophycin-52, showed a 10-20-fold higher biological activity using the same cell lines and test conditions $\left(I C_{50}=0.07 \mathrm{nM}\right.$ and $0.02 \mathrm{nM}$ in M21 and M21-L cells, respectively). Furthermore, the Gly-Pro-Cry-55gly (12) metabolite was similarly active as the free payload, suggesting that inefficient drug release does not compromise biological activity. These data demonstrate that esterification of the chlorohydrin with glycine or Gly-Pro-Gly 
tripeptide may result only in a slightly decreased potency compared to cryptophycin-52, likely due to different membrane permeability or lower tubulin binding affinity of these derivatives.

Table 1. Cytotoxic potencies of cryptophycin-55 glycinate (4), drug-containing metabolite 12, and bioconjugates $\mathbf{1 0}$ and $\mathbf{1 1}$ against M21 and M21-L human melanoma cells.

\begin{tabular}{cccc}
\hline \multirow{2}{*}{ Entry } & \multirow{2}{*}{ Compound } & \multicolumn{2}{c}{$I C_{\mathbf{5 0}}(\mathbf{n M})$} \\
\cline { 3 - 4 } & & $\mathbf{M 2 1}\left(\alpha_{\mathbf{v}} \beta_{\mathbf{3}}+\right)$ & M21-L $\left(\alpha_{\mathbf{v}}, \alpha_{\mathbf{v}} \beta_{\mathbf{3}}-\right)$ \\
\hline 1 & Cry-55gly (4) & $0.75 \pm 0.11$ & $0.14 \pm 0.08$ \\
2 & Gly-Pro-Cry-55gly (12) & $0.15 \pm 0.03$ & $0.039 \pm 0.01$ \\
3 & $c($ RGDfK)-Val-Cit-PABC-Cry-55gly (10) & $7.63 \pm 0.76$ & $5.80 \pm 4.30$ \\
4 & $c($ RGDfK)-Val-Cit-Gly-Pro-Cry-55gly (11) & $0.16 \pm 0.02$ & $0.15 \pm 0.02$ \\
\hline
\end{tabular}
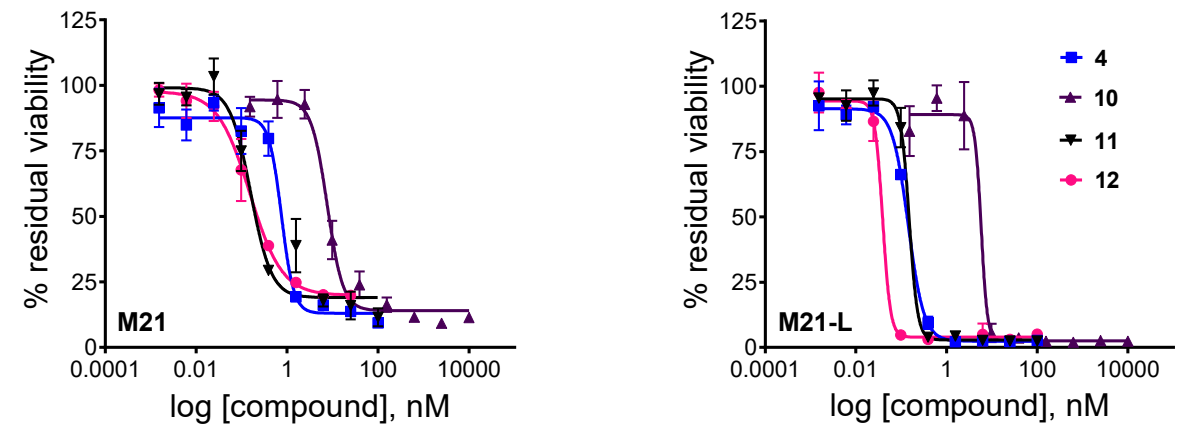

Figure 4. Cytotoxic effect of unconjugated cryptophycin-55 glycinate (4), conjugates 10, 11, and metabolite 12 against M21 and M21-L human melanoma cells after $72 \mathrm{~h}$ ( $2 \mathrm{~h}$ treatment and additional $70 \mathrm{~h}$ incubation). Curves obtained by non-linear regression (four-parameter dose-response, error bars represent the standard deviation of triplicates, the measurements were repeated twice).

Both conjugates are highly potent; the determined $I C_{50}$ values are within a range of $0.15-7.63 \mathrm{nM}$. Conjugate 10 containing the Val-Cit-PABC linker shows slightly reduced activity compared to cryptophycin-55 glycinate, while conjugate 11 bearing the Val-Cit-Gly-Pro linker shows equal potency to that of metabolite 12. Moreover, conjugate 11 was $\sim 300$-fold more potent compared to the model compound azido-functionalized cryptophycin-RGD conjugate [18], verifying the potential of cryptophycin-based conjugates containing cleavable linkers.

Both conjugates exhibit similar cytotoxicity against the antigen-positive and antigen-negative cell line, indicating that there is no apparent correlation between the integrin $\alpha_{\mathrm{v}} / \alpha_{\mathrm{v}} \beta_{3}$ expression level and the observed in vitro potency. It has been shown, similarly, that cytotoxicity of the RGD peptidomimetic- $\alpha$-amanitin conjugates was not integrin-specific when tested on human glioblastoma U-87 $\left(\alpha_{\mathrm{v}} \beta_{3}+\right)$ and breast adenocarcinoma MDA-MB-468 $\left(\alpha_{\mathrm{v}} \beta_{3^{-}}\right)$cells, and it was then proposed that the internalization process was mediated by integrins different from $\alpha_{v} \beta_{3}$ (e.g., $\alpha_{v} \beta_{5}$ ) [57]. To better understand these findings, confocal microscopy studies were performed to investigate the delivery and uptake of RGD-conjugates in M21 and M21-L human melanoma cells.

\subsection{Intracellular Uptake Studies}

To explore cell surface binding and delivery of RGD conjugates, two analogous conjugates were synthetized, in which the cytotoxic payload was replaced with the infrared dye, cyanine5.5. Self-immolative linkers 5 and 6 were reacted with the Cy5.5 amine in good yields giving compounds 13 and 14 (Scheme S4). Fluorescently labeled conjugates 15 and 16 were obtained in satisfactory yields and excellent purity by $\mathrm{CuAAC}$ click reaction with the azido-functionalized RGD-ligand 9. Confocal microscopy studies were carried out with living M21 and M21-L cells. Similar binding and intracellular uptake could be observed for the two fluorescently labeled compounds in both cell lines after a period of $30 \mathrm{~min}$ (Figure S6). The intracellular uptake of compounds 15 and 16 in the M21-L cells indicates 
that internalization of these is mediated by a process independent of $\alpha_{\mathrm{v}}$-integrin. The results, applying constructs of $c$ (RGDfK)-linker-fluorescent dye, are consistent with previous reports showing that endocytosis of cyclo-RGD peptides is integrin independent and follows a fluid phase uptake [58]. In a different study, an $\alpha_{v} \beta_{3}$-independent uptake was confirmed for the monomeric RGD-peptide, while the multimeric RAFT-RGD-Cy5 was efficiently internalized with integrin $\alpha_{\mathrm{v}} \beta_{3}$ via clathrin-mediated endocytosis [59]. All these findings support the explanation that a non-integrin-mediated uptake of the cryptophycin-conjugates $\mathbf{1 0}$ and $\mathbf{1 1}$ can be accounted for the observed in vitro potencies.

Apart from the involvement of the targeting RGD-ligand for the internalization of the SMDCs, the high hydrophobicity of the cytotoxic payload may significantly accelerate the uptake of the RGD-cryptophycin conjugates, and thus compromise the in vitro selectivity. In fact, it was shown that the uptake of ${ }^{3} \mathrm{H}$-cryptophycin-52 by THP-1 and $\mathrm{H}-125$ cells was rapid, reaching a plateau within $20 \mathrm{~min}$, and irreversible, as no dissociation or efflux from the cells was observed [60]. In a separate experiment, ${ }^{3} \mathrm{H}$-cryptophycin-52 became 730 -fold more concentrated in HeLa cells upon $20 \mathrm{~h}$ incubation [61]. Although the short treatment time in the cytotoxicity assay aimed to minimize such undesired interactions, a nonspecific endocytic process mediated by the hydrophobic payload, that promotes internalization of the conjugates in the antigen-negative cells, cannot be excluded.

\section{Conclusions}

In summary, we have described the synthesis of two novel integrin-targeted SMDCs based on the conjugation of the highly potent cytotoxic payload, cryptophycin-55 glycinate, to the $c$ (RGDfK) integrin ligand through the protease sensible Val-Cit dipeptide linker combined with the PABC or Gly-Pro self-immolative moieties. First, it was shown that our selected payload is remarkably more stable in mouse plasma compared to the parent compound, cryptophycin-52, and it is not affected by ester or amide hydrolysis. The exceptional stability of cryptophycin-55 glycinate verifies its development as SMDC payload. Secondly, it was found that the biological and biochemical properties of the conjugates strongly depend on the linker type. On one hand, conjugate $\mathbf{1 0}$ bearing the Val-Cit-PABC linker exhibited satisfactory stability in mouse plasma, and it was highly stable in human plasma. Furthermore, its linker was efficiently cleaved in the presence of cathepsin B releasing free cryptophycin-55 glycinate. The conjugate displayed high in vitro potency against M21 and M21-L human melanoma cells with $I C_{50}$ values in the low nanomolar range. On the other hand, conjugate 11 with the Val-Cit-Gly-Pro peptide linker showed excellent stability both in mouse and human plasma. Enzymatic linker cleavage resulted in the release of the Gly-Pro-Cry-55gly (12) metabolite, indicating the lack of an efficient self-immolation step. Despite the inefficient release of the free drug, conjugate 11 showed enhanced potency compared to conjugate 10, with $I C_{50}$ values in the sub nanomolar range.

Finally, the excellent in vitro activity of the novel bioconjugates was accompanied with inferior selectivity for cell lines with different integrin $\alpha_{v} \beta_{3}$ expression level. These results indicate that the RGD-cryptophycin conjugates are internalized by a nonspecific process, which can be attributed both to the RGD ligand and the high hydrophobicity of the payload and/or conjugates. In the light of these results, further opportunities arise for the design of novel cryptophycin-based therapeutic agents with improved tumor selectivity.

Supplementary Materials: The following are available online at http:/ / www.mdpi.com/1999-4923/11/4/151/s1: General information, Synthetic procedures: Synthesis of alkyne-functionalized PEG5-linker (19), Synthesis of alkynyl-PEG5-Val-Cit-PABC-PNP linker (5), Synthesis of alkynyl-PEG5-Val-Cit-Gly-Pro linker (6), Synthesis of azido-functionalized RGD-ligand (9), Synthesis of Cy5.5 labeled conjugates 15 and 16, Characterization details for compounds 5-23. Figure S1: Plasma stability of cryptophycin-52 (A) and cryptophycin-55 glycinate (B). Metabolism of cryptophycin-52 in mouse plasma (C) and the structure of the detected metabolites (D), Table S1: Major metabolites of $\mathbf{1 0}$ identified after $24 \mathrm{~h}$ incubation with mouse and human plasma: proposed structure of metabolites, including also their chemical formula, $m / z$, retention time (RT), and occurrence (ND: not detected); Figure S2: Plot of the compound 10 and metabolites vs. incubation time (h), Figure S3: Degradation of conjugate 10 by incubation with lysosomal homogenate for $2 \mathrm{~h}$ and the release of cryptophycin-55 glycinate (4), Figure S4: Degradation of conjugate $\mathbf{1 1}$ by incubation with lysosomal homogenate for $2 \mathrm{~h}$ and the release of Gly-Pro-Cry-55gly (12), Figure S5: Flow cytometry analysis of integrin $\alpha_{V}$ and $\alpha_{V} \beta_{3}$ expression in M21 and M21-L cell lines, Figure S6: 
Binding and internalization of compounds 15 and $16(1 \mu \mathrm{M})$ in live M21 and M21-L human melanoma cells after incubation at $37^{\circ} \mathrm{C}$ for $30 \mathrm{~min}$. Scheme S1: Synthesis of alkyne-functionalized PEG5-linker (19), Scheme S2: Synthesis of Alkynyl-PEG5-Val-Cit-PABC-PNP (5), Scheme S3: Synthesis of azido-functionalized RGD-ligand (9), Scheme S4. Synthesis of conjugates 15 and 16.

Author Contributions: The project was conceived and designed by A.B., E.F. and N.S. with valuable inputs from the rest of the authors. RGD-cryptophycin conjugates and Cy5.5 labeled compounds were synthesized and characterized by A.B.; compound 19 was synthetized and characterized by E.F.; plasma stability and lysosomal degradation assay were carried out by A.B. and G.A.; data analysis and metabolite identification were done by A.B. and S.E.; plasma stability and lysosomal degradation experimental designs were done by A.B., A.D.M., E.M., and V.S.; integrin binding assay was performed by I.K.; cathepsin B cleavage assay was carried out by P.C. and R.P.; cell culturing and in vitro cytotoxicity assays were done by A.M., in consultation with P.G. and C.S.; confocal microscopy images were recorded by A.M.; the project administration was done by M.F.; the manuscript and the supporting information were written by A.B. All authors read and revised the manuscript.

Funding: This project has received funding from the European Union's Horizon 2020 research and innovation programme under the Marie Sklodowska-Curie grant agreement No 642004 (ETN MAGICBULLET). We acknowledge the financial support of the German Research Foundation (DFG) and the Open Access Publication Fund of Bielefeld University for the article processing charge.

Acknowledgments: The authors want to acknowledge Georg Falck for flow cytometry analysis, Marco Wißbrock, Anke Nieß, and Carmela Michalek for technical support. Human melanoma cells (M21 and M21-L) were kindly provided by David Cheresh and The Scripps Research Institute (La Jolla, CA, USA).

Conflicts of Interest: A.M. is an employee of Exiris, P.C., and R.P. are employees of Italfarmaco. S.E., G.A., E.M., A.D.M., and V.S. are employees of IRBM. P.G. is a shareholder of Exiris. C.S. is an employee of Italfarmaco and a shareholder of Exiris.

\section{References}

1. Chari, R.V.J.; Miller, M.L.; Widdison, W.C. Antibody-Drug Conjugates: An Emerging Concept in Cancer Therapy. Angew. Chem. Int. Ed. 2014, 53, 3796-3827. [CrossRef]

2. Srinivasarao, M.; Galliford, C.V.; Low, P.S. Principles in the Design of Ligand-Targeted Cancer Therapeutics and Imaging Agents. Nat. Rev. Drug Discov. 2015, 14, 203-219. [CrossRef] [PubMed]

3. Vrettos, E.I.; Mező, G.; Tzakos, A.G. On the Design Principles of Peptide-drug Conjugates for Targeted Drug Delivery to the Malignant Tumor Site. Beilstein J. Org. Chem. 2018, 14, 930-954. [CrossRef] [PubMed]

4. Krall, N.; Scheuermann, J.; Neri, D. Small Targeted Cytotoxics: Current State and Promises from DNA-Encoded Chemical Libraries. Angew. Chem. Int. Ed. 2013, 52, 1384-1402. [CrossRef]

5. William, D.H.; Tamer, E.F.; Hossam, M.A.; Hongbing, W.; Hanzem, E.H. Antibody-Drug Conjugates: Pharmacokinetic/Pharmacodynamic Modeling, Preclinical Characterization, Clinical Studies, and Lessons Learned. Clin. Pharmacokinet. 2018, 57, 687-703.

6. Casi, G.; Neri, D. Antibody-Drug Conjugates and Small Molecule-Drug Conjugates: Opportunities and Challenges for the Development of Selective Anticancer Cytotoxic Agents. J. Med. Chem. 2015, 58, 8751-8761. [CrossRef]

7. Cazzamalli, S.; Corso, A.D.; Neri, D. Targeted Delivery of Cytotoxic Drugs: Challenges, Opportunities and New Developments. Chim. Int. J. Chem. 2017, 71, 712-715. [CrossRef]

8. Deonarain, M.; Yahioglu, G.; Stamati, I.; Pomowski, A.; Clarke, J.; Edwards, B.; Diez-Posada, S.; Stewart, A. Small-Format Drug Conjugates: A Viable Alternative to ADCs for Solid Tumours? Antibodies 2018, 7, 16. [CrossRef]

9. Schwartz, R.E.; Hirsch, C.F.; Sesin, D.F.; Flor, J.E.; Chartrain, M.; Fromtling, R.E.; Harris, G.H.; Salvatore, M.J.; Liesch, J.M.; Yudin, K. Pharmaceuticals from Cultured Algae. J. Ind. Microbiol. 1990, 5, 113-123. [CrossRef]

10. Panda, D.; Himes, R.H.; Moore, R.E.; Wilson, L.; Jordan, M.A. Mechanism of Action of the Unusually Potent Microtubule Inhibitor Cryptophycin 1. Biochemistry 1997, 36, 12948-12953. [CrossRef] [PubMed]

11. Barbier, P.; Gregoire, C.; Devred, F.; Sarrazin, M.; Peyrot, V. In Vitro Effect of Cryptophycin 52 on Microtubule Assembly and Tubulin: Molecular Modeling of the Mechanism of Action of a New Antimitotic Drug. Biochemistry 2001, 40, 13510-13519. [CrossRef]

12. Smith, C.D.; Zhang, X.; Mooberry, S.L.; Patterson, G.M.L.; Moore, R.E. Cryptophycin: A New Antimicrotubule Agent Active against Drug-Resistant Cells. Cancer Res. 1994, 54, 3779-3784. [PubMed] 
13. Edelman, M.J.; Gandara, D.R.; Hausner, P.; Israel, V.; Thornton, D.; DeSanto, J.; Doyle, L.A. Phase 2 Study of Cryptophycin 52 (LY355703) in Patients Previously Treated with Platinum Based Chemotherapy for Advanced Non-Small Cell Lung Cancer. Lung Cancer 2003, 39, 197-199. [CrossRef]

14. D'Agostino, G.; del Campo, J.; Mellado, B.; Izquierdo, M.A.; Minarik, T.; Cirri, L.; Marini, L.; Perez-Gracia, J.L.; Scambia, G. A Multicenter Phase II Study of the Cryptophycin Analog LY355703 in Patients with Platinum-Resistant Ovarian Cancer. Int. J. Gynecol. Cancer 2006, 16, 71-76. [CrossRef] [PubMed]

15. Sammet, B.; Bogner, T.; Nahrwold, M.; Weiss, C.; Sewald, N. Approaches for the Synthesis of Functionalized Cryptophycins. J. Org. Chem. 2010, 75, 6953-6960. [CrossRef]

16. Weiss, C.; Sammet, B.; Sewald, N. Recent Approaches for the Synthesis of Modified Cryptophycins. Nat. Prod. Rep. 2013, 30, 924-940. [CrossRef]

17. Figueras, E.; Borbély, A.; Ismail, M.; Frese, M.; Sewald, N. Novel Unit B Cryptophycin Analogues as Payloads for Targeted Therapy. Beilstein J. Org. Chem. 2018, 14, 1281-1286. [CrossRef]

18. Nahrwold, M.; Weiß, C.; Bogner, T.; Mertink, F.; Conradi, J.; Sammet, B.; Palmisano, R.; Royo Gracia, S.; Preuße, T.; Sewald, N. Conjugates of Modified Cryptophycins and RGD-Peptides Enter Target Cells by Endocytosis. J. Med. Chem. 2013, 56, 1853-1864. [CrossRef]

19. Bouchard, H.; Brun, M.-P.; Commercon, A.; Zhang, J. Conjugates, Preparation Thereof, and Therapeutic Use Thereof. U.S. Patent 8952147B2, 10 February 2015.

20. Verma, V.A.; Pillow, T.H.; DePalatis, L.; Li, G.; Phillips, G.L.; Polson, A.G.; Raab, H.E.; Spencer, S.; Zheng, B. The Cryptophycins as Potent Payloads for Antibody Drug Conjugates. Bioorg. Med. Chem. Lett. 2015, 25, 864-868. [CrossRef]

21. Weiss, C.; Figueras, E.; Borbely, A.N.; Sewald, N. Cryptophycins: Cytotoxic Cyclodepsipeptides with Potential for Tumor Targeting. J. Pept. Sci. 2017, 23, 514-531. [CrossRef] [PubMed]

22. Bouchard, H.; Brun, M.-P.; Hubert, P. Novel Peptidic Linkers and Cryptophycin Conjugates, their Preparation and their Therapeutic Use. US2018/0369401 A1, 27 December 2018.

23. Liang, J.; Moore, R.E.; Moher, E.D.; Munroe, J.E.; Al-awar, R.S.; Hay, D.A.; Varie, D.L.; Zhang, T.Y.; Aikins, J.A.; Martinelli, M.J.; et al. Cryptophycins-309, 249 and Other Cryptophycin Analogs: Preclinical Efficacy Studies with Mouse and Human Tumors. Investig. New Drugs 2005, 23, 213-224. [CrossRef] [PubMed]

24. Steinkühler, C.; Gallinari, P.; Osswald, B.; Sewald, N.; Ritzefeld, M.; Frese, M.; Figueras, E.; Pethö, L. Cryptophycin-Based Antibody-Drug Conjugates with Novel Self-Immolative Linkers. WO2016/146638 A1, 22 September 2016.

25. Cazzamalli, S.; Figueras, E.; Pethő, L.; Borbély, A.; Steinkühler, C.; Neri, D.; Sewald, N. In Vivo Antitumor Activity of a Novel Acetazolamide-Cryptophycin Conjugate for the Treatment of Renal Cell Carcinomas. ACS Omega 2018, 3, 14726-14731. [CrossRef] [PubMed]

26. Figueras, E.; Martins, A.; Borbély, A.; Le Joncour, V.; Cordella, P.; Perego, R.; Modena, D.; Pagani, P.; Esposito, S.; Auciello, G.; et al. Octreotide Conjugates for Tumor Targeting and Imaging. manuscript in preparation.

27. Hamidi, H.; Ivaska, J. Every Step of the Way: Integrins in Cancer Progression and Metastasis. Nat. Rev. Cancer 2018, 18, 533-548. [CrossRef]

28. Desgrosellier, J.S.; Cheresh, D.A. Integrins in Cancer: Biological Implications and Therapeutic Opportunities. Nat. Rev. Cancer 2010, 10, 9-22. [CrossRef] [PubMed]

29. Danhier, F.; Le Breton, A.; Préat, V. RGD-Based Strategies To Target Alpha(v) Beta(3) Integrin in Cancer Therapy and Diagnosis. Mol. Pharm. 2012, 9, 2961-2973. [CrossRef]

30. Nieberler, M.; Reuning, U.; Reichart, F.; Notni, J.; Wester, H.-J.; Schwaiger, M.; Weinmüller, M.; Räder, A.; Steiger, K.; Kessler, H. Exploring the Role of RGD-Recognizing Integrins in Cancer. Cancers 2017, 9, 116. [CrossRef] [PubMed]

31. Ruoslahti, E.; Pierschbacher, M. New Perspectives in Cell Adhesion: RGD and Integrins. Science 1987, 238, 491-497. [CrossRef] [PubMed]

32. Da Ressurreição, A.S.M.; Vidu, A.; Civera, M.; Belvisi, L.; Potenza, D.; Manzoni, L.; Ongeri, S.; Gennari, C.; Piarulli, U. Cyclic RGD-Peptidomimetics Containing Bifunctional Diketopiperazine Scaffolds as New Potent Integrin Ligands. Chem. Eur. J. 2009, 15, 12184-12188. [CrossRef] [PubMed]

33. Urman, S.; Gaus, K.; Yang, Y.; Strijowski, U.; Sewald, N.; De Pol, S.; Reiser, O. The Constrained Amino Acid $\beta$-Acc Confers Potency and Selectivity to Integrin Ligands. Angew. Chem. Int. Ed. 2007, 46, 3976-3978. [CrossRef] [PubMed] 
34. Kapp, T.G.; Rechenmacher, F.; Neubauer, S.; Maltsev, O.V.; Cavalcanti-Adam, E.A.; Zarka, R.; Reuning, U.; Notni, J.; Wester, H.-J.; Mas-Moruno, C.; et al. A Comprehensive Evaluation of the Activity and Selectivity Profile of Ligands for RGD-Binding Integrins. Sci. Rep. 2017, 7, 39805. [CrossRef] [PubMed]

35. Stupp, R.; Hegi, M.E.; Gorlia, T.; Erridge, S.C.; Perry, J.; Hong, Y.; Aldape, K.D.; Lhermitte, B.; Pietsch, T.; Grujicic, D.; et al. Cilengitide Combined with Standard Treatment for Patients with Newly Diagnosed Glioblastoma with Methylated MGMT Promoter (CENTRIC EORTC 26071-22072 Study): A Multicentre, Randomised, Open-Label, Phase 3 Trial. Lancet Oncol. 2014, 15, 1100-1108. [CrossRef]

36. Garanger, E.; Boturyn, D.; Dumy, P. Tumor Targeting with RGD Peptide Ligands-Design of New Molecular Conjugates for Imaging and Therapy of Cancers. Anticancer Agents Med. Chem. 2007, 7, 552-558. [CrossRef]

37. Chen, H.; Niu, G.; Wu, H.; Chen, X. Clinical Application of Radiolabeled RGD Peptides for PET Imaging of Integrin $\alpha_{\mathrm{v}} \beta_{3}$. Theranostics 2016, 6, 78-92. [CrossRef]

38. Dal Corso, A.; Pignataro, L.; Belvisi, L.; Gennari, C. $\alpha_{v} \beta_{3}$ Integrin-Targeted Peptide/Peptidomimetic-Drug Conjugates: In-Depth Analysis of the Linker Technology. Curr. Top. Med. Chem. 2016, 16, 314-329. [CrossRef] [PubMed]

39. Katsamakas, S.; Chatzisideri, T.; Thysiadis, S.; Sarli, V. RGD-Mediated Delivery of Small-Molecule Drugs. Future Med. Chem. 2017, 9, 579-604. [CrossRef]

40. Chatzisideri, T.; Leonidis, G.; Sarli, V. Cancer-Targeted Delivery Systems Based on Peptides. Future Med. Chem. 2018, 10, 2201-2226. [CrossRef] [PubMed]

41. Araste, F.; Abnous, K.; Hashemi, M.; Taghdisi, S.M.; Ramezani, M.; Alibolandi, M. Peptide-Based Targeted Therapeutics: Focus on Cancer Treatment. J. Control. Release 2018, 292, 141-162. [CrossRef]

42. Esposito, S.; Mele, R.; Ingenito, R.; Bianchi, E.; Bonelli, F.; Monteagudo, E.; Orsatti, L. An Efficient Liquid Chromatography-High Resolution Mass Spectrometry Approach for the Optimization of the Metabolic Stability of Therapeutic Peptides. Anal. Bioanal. Chem. 2017, 409, 2685-2696. [CrossRef]

43. Veronese, F.M.; Schiavon, O.; Pasut, G.; Mendichi, R.; Andersson, L.; Tsirk, A.; Ford, J.; Wu, G.; Kneller, S.; Davies, J.; et al. PEG-Doxorubicin Conjugates: Influence of Polymer Structure on Drug Release, in Vitro Cytotoxicity, Biodistribution, and Antitumor Activity. Bioconj. Chem. 2005, 16, 775-784. [CrossRef] [PubMed]

44. Beck, A.; Goetsch, L.; Dumontet, C.; Corvaïa, N. Strategies and Challenges for the next Generation of Antibody-Drug Conjugates. Nat. Rev. Drug Discov. 2017, 16, 315-337. [CrossRef]

45. Dubowchik, G.M.; Firestone, R.A.; Padilla, L.; Willner, D.; Hofstead, S.J.; Mosure, K.; Knipe, J.O.; Lasch, S.J.; Trail, P.A. Cathepsin B-Labile Dipeptide Linkers for Lysosomal Release of Doxorubicin from Internalizing Immunoconjugates: Model Studies of Enzymatic Drug Release and Antigen-Specific in Vitro Anticancer Activity. Bioconj. Chem. 2002, 13, 855-869. [CrossRef]

46. Caculitan, N.G.; dela Cruz Chuh, J.; Ma, Y.; Zhang, D.; Kozak, K.R.; Liu, Y.; Pillow, T.H.; Sadowsky, J.; Cheung, T.K.; Phung, Q.; et al. Cathepsin B Is Dispensable for Cellular Processing of Cathepsin B-Cleavable Antibody-Drug Conjugates. Cancer Res. 2017, 77, 7027-7037. [CrossRef] [PubMed]

47. Lee, B.-C.; Chalouni, C.; Doll, S.; Nalle, S.C.; Darwish, M.; Tsai, S.P.; Kozak, K.R.; Del-Rosario, G.; Yu, S.-F.; Erickson, H.; et al. FRET Reagent Reveals the Intracellular Processing of Peptide-Linked Antibody-Drug Conjugates. Bioconj. Chem. 2018, 29, 2468-2477. [CrossRef] [PubMed]

48. Battersby, J.E.; Hancock, W.S.; Canova-Davis, E.; Oeswein, J.; O'Onnor, B. Diketopiperazine Formation and N-Terminal Degradation in Recombinant Human Growth Hormone. Int. J. Pept. Protein Res. 1994, 44, 215-222. [CrossRef]

49. DiMarchi, R.D.; Brooke, G.S. Selective Chemical Removal of a Protein Amino-Terminal Residue. US4782139, 1 November 1988.

50. Su, D.; Kozak, K.R.; Sadowsky, J.; Yu, S.-F.; Fourie-O’Donohue, A.; Nelson, C.; Vandlen, R.; Ohri, R.; Liu, L.; $\mathrm{Ng}$, C.; et al. Modulating Antibody-Drug Conjugate Payload Metabolism by Conjugation Site and Linker Modification. Bioconj. Chem. 2018, 29, 1155-1167. [CrossRef]

51. Dorywalska, M.; Dushin, R.; Moine, L.; Farias, S.E.; Zhou, D.; Navaratnam, T.; Lui, V.; Hasa-Moreno, A.; Casas, M.G.; Tran, T.-T.; et al. Molecular Basis of Valine-Citrulline-PABC Linker Instability in Site-Specific ADCs and Its Mitigation by Linker Design. Mol. Cancer Ther. 2016, 15, 958-970. [CrossRef]

52. Cazzamalli, S.; Dal Corso, A.; Neri, D. Linker Stability Influences the Anti-Tumor Activity of Acetazolamide-Drug Conjugates for the Therapy of Renal Cell Carcinoma. J. Control. Release 2017, 246, $39-45$. [CrossRef] 
53. Gikanga, B.; Adeniji, N.S.; Patapoff, T.W.; Chih, H.W.; Yi, L. Cathepsin B Cleavage of VcMMAE-Based Antibody-Drug Conjugate Is Not Drug Location or Monoclonal Antibody Carrier Specific. Bioconj. Chem. 2016, 27, 1040-1049. [CrossRef]

54. Manabe, S.; Machida, H.; Aihara, Y.; Yasunaga, M.; Ito, Y.; Matsumura, Y. Development of a Diketopiperazine-Forming Dipeptidyl Gly-Pro Spacer for Preparation of an Antibody-Drug Conjugate. Medchemcomm 2013, 4, 792-796. [CrossRef]

55. Cheresh, D.A.; Spiro, R.C. Biosynthetic and Functional Properties of an Arg-Gly-Asp-Directed Receptor Involved in Human Melanoma Cell Attachment to Vitronectin, Fibrinogen, and von Willebrand Factor. J. Biol. Chem. 1987, 262, 17703-17711.

56. Felding-Habermann, B.; Mueller, B.M.; Romerdahl, C.A.; Cheresh, D.A. Involvement of Integrin $\alpha_{\mathrm{v}}$ Gene Expression in Human Melanoma Tumorigenicity. J. Clin. Investig. 1992, 89, 2018-2022. [CrossRef] [PubMed]

57. Bodero, L.; López Rivas, P.; Korsak, B.; Hechler, T.; Pahl, A.; Müller, C.; Arosio, D.; Pignataro, L.; Gennari, C.; Piarulli, U. Synthesis and Biological Evaluation of RGD and isoDGR Peptidomimetic- $\alpha$-Amanitin Conjugates for Tumor-Targeting. Beilstein J. Org. Chem. 2018, 14, 407-415. [CrossRef] [PubMed]

58. Castel, S.; Pagan, R.; Mitjans, F.; Piulats, J.; Goodman, S.; Jonczyk, A.; Huber, F.; Vilaró, S.; Reina, M. RGD Peptides and Monoclonal Antibodies, Antagonists of $\alpha_{\mathrm{V}}$-Integrin, Enter the Cells by Independent Endocytic Pathways. Lab. Investig. 2001, 81, 1615-1626. [CrossRef]

59. Lucie, S.; Elisabeth, G.; Stéphanie, F.; Guy, S.; Amandine, H.; Corinne, A.R.; Didier, B.; Catherine, S.; Alexeï, G.; Pascal, D.; et al. Clustering and Internalization of Integrin $\alpha_{\mathrm{v}} \beta_{3}$ with a Tetrameric RGD-Synthetic Peptide. Mol. Ther. 2009, 17, 837-843. [CrossRef] [PubMed]

60. Chen, B.D.C.; Nakeff, A.N.; Valeriote, F.V. Cellular Uptake of a Novel Cytotoxic Agent, Cryptophycin-52, by Human THP-1 Leukemia Cells and H-125 Lung Tumor Cells. Int. J. Cancer 1998, 77, 869-873. [CrossRef]

61. Panda, D.; DeLuca, K.; Williams, D.; Jordan, M.A.; Wilson, L. Antiproliferative Mechanism of Action of Cryptophycin-52: Kinetic Stabilization of Microtubule Dynamics by High-Affinity Binding to Microtubule Ends. Proc. Natl. Acad. Sci. USA 1998, 95, 9313-9318. [CrossRef] [PubMed] 